\title{
Seasonal Variation in Fasting Plasma Glucose Levels in Man
}

\author{
L. Suarez and E. Barrett-Connor \\ Departments of Community and Family Medicine and Medicine, School of Medicine, University of California, San Diego, California, USA
}

\begin{abstract}
Summary. A Southern California community study of 4,541 men and women (aged 20-79 years) showed significant seasonal variation in fasting plasma glucose. There was a mean $0.6 \mathrm{mmol} / 1$ difference between highest levels in winter and lowest levels in spring. This difference was consistent over a two-year period, similar at all ages and seen in both men and women. Fasting plasma glucose levels correlated directly with percentage possible sunshine $(p=0.03)$ and inversely with temperature $(p=0.04)$. Adjustment for the level of measured obesity did not alter the observed association, but a history of recent weight gain corresponded to the season of maximum fasting plasma glucose level.
\end{abstract}

Key words: Community study, fasting plasma glucose, obesity, seasonal variation.

With the recent emphasis on fasting plasma glucose (FPG) levels as one criterion for the diagnosis of diabetes mellitus [1], it is important to identify non-disease variables that alter FPG. Although studies in animals have shown lower insulin resistance and altered glucose metabolism during the summer months [2-7], there have been only two small studies of seasonal variation of FPG in man, both in men living in extreme climates. In Sweden a cross-sectional study of 100 male survivors of myocardial infarction showed significant seasonal variation in FPG, with the lowest levels in the warmer, lighter months of spring and summer [8]. These differences paralleled changes in log sum insulin concentrations and were said to be unexplained by body weight or age. In a prospective study, 12 young men were examined in March, June, September and December while working 900 miles from the South Pole [9]. In this environment the temperature ranges from $-40^{\circ} \mathrm{C}$ in winter to an average of $0{ }^{\circ} \mathrm{C}$ in summer, and there are periods of continuous daylight (summer) or continuous dark (winter). Blood glucose levels again were lowest in summer (December). No significant seasonal variation in diet or energy expenditure was noted.

Data from a large cross-sectional populationbased study in Southern California have been analyzed to determine whether significant seasonal variation in FPG also occurs in a moderate climate.

\section{Methods}

From 1972 to $1974,82 \%$ of all adult residents of a geographically defined upper middle class white community in San Diego County participated in a survey for heart disease risk factors. All subjects were asked about a history of diabetes; women were asked about current pregnancy and the use of oral contraceptives or replacement oestrogens. Venipuncture was performed on fasting subjects between 0700 and $1100 \mathrm{~h}$. Blood glucose was determined by the hexokinase method. Height and weight were measured in light clothing without shoes. Obesity was calculated as body mass index (weight/height ${ }^{2}$ ). A $15 \%$ random sample of the subjects was examined more extensively, including a standardized interview with questions designed to assess exercise and weight change during the preceding 2 weeks and a 24 -h diet recall obtained by a certified dietitian utilizing food models to ascertain portion size. Analysis of variance methods were used to assess seasonal differences in fasting plasma glucose and other variables.

\section{Results}

Data are reported for all subjects aged 20-79 years, after exclusion of persons who had a history of diabetes, who had not fasted at least $12 \mathrm{~h}$ before venipuncture, or who were pregnant (Table 1). A significant seasonal variation in FPG was observed with a mean $0.6 \mathrm{mmol} / 1$ difference between the highest lev- 
els in the winter (December-February) and the lowest levels in the spring (March-May) (Fig. 1). This seasonal pattern was consistent across the 2 -year period of investigation (Fig.2) and across three age strata

Table 1. Age-sex distribution of subjects studied by season of visit

\begin{tabular}{lccccc}
\hline & \multicolumn{2}{l}{ Men } & & \multicolumn{2}{l}{ Women } \\
\cline { 2 - 3 } \cline { 5 - 6 } \cline { 5 - 6 } & No. & $\begin{array}{l}\text { Mean age } \\
\text { (years) }\end{array}$ & & No. & $\begin{array}{l}\text { Mean age } \\
\text { (years) }\end{array}$ \\
\hline December-February & 519 & 58.1 & & 608 & 57.4 \\
March-May & 536 & 55.4 & & 637 & 54.7 \\
June-August & 321 & 56.5 & & 422 & 55.3 \\
September-November & 664 & 59.4 & & 834 & 57.6 \\
\hline Total & 2040 & 57.6 & 2501 & 56.4 \\
\hline
\end{tabular}

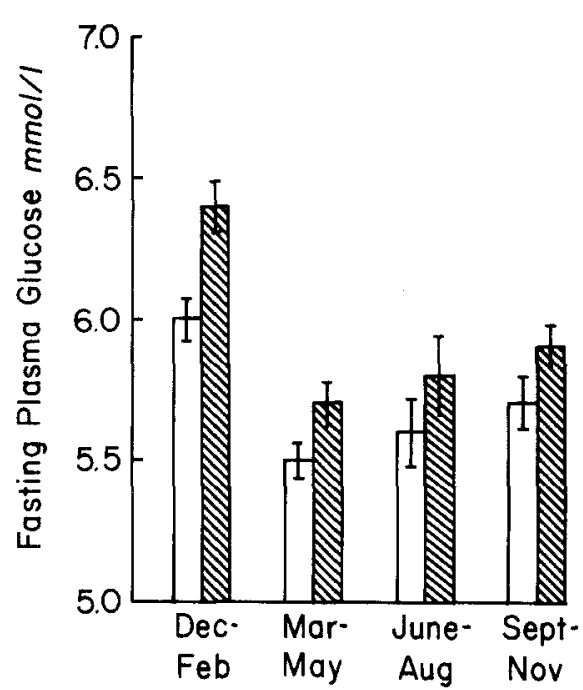

Fig. 1. Seasonal distribution of mean fasting plasma glucose levels among 2040 men and 2501 women $\square$. Bars indicate $95 \%$ confidence interval
(20-39; 40-59; 60-79 years) (Table 2). Thus, although subjects studied in winter months tended to be older than those studied at other times, and although FPG increases modestly with age $(0.11 \mathrm{mmol} / 1 \mathrm{per}$ decade), the seasonal variation was not a function of the age distribution of sampling. Also, although women had lower FPG levels than men at each season, the degree of seasonal variation was similar for men and women and was independent of current use or nonuse of exogenous oestrogens (either oral contraceptives or replacement oestrogens) in women (Table 2).

The seasonal variation in FPG was examined for an association with climatological phenomena and seasonal patterns of obesity, diet and exercise. As shown in Figure 2, based on local climatological data for the same years from the US Department of Commerce, FPG levels correlated directly and significantly with percentage possible sunshine $(p=0.03)$ and inversely with temperature $(p=0.04)$. In this population, the obesity index varied by season, with the highest levels in winter ( $p=0.02$ in men; $p=0.12$ in women) corresponding to the highest FPG levels. However, seasonal variation in FPG remained essentially unchanged after adjustment for obesity (Table 3). To determine whether weight change follows the seasonal pattern of FPG, the data were analyzed from the $15 \%$ random sample who answered the question about net weight change within the past 2 weeks. The seasonal distribution presented in Table 4 shows that weight gain was reported only for winter months (December-February) by both men and women, although the reported gain was not statistically significant. No seasonal differences in total calories, protein, fat, carbohydrate, or alcohol consumption were found in this sample. Similarly, there was no significant seasonal variation in reported vigorous exercise.

Table 2. Seasonal variation in fasting plasma glucose (FPG) levels among men and women by age and hormone use

\begin{tabular}{|c|c|c|c|c|c|c|c|c|}
\hline \multirow[t]{2}{*}{ Age (years) } & \multicolumn{2}{|c|}{ December-February } & \multicolumn{2}{|l|}{ March-May } & \multicolumn{2}{|l|}{ June-August } & \multicolumn{2}{|c|}{ September-November } \\
\hline & $\mathrm{FPG}(\mathrm{mmol} / \mathrm{l})$ & No. & $\mathrm{FPG}(\mathrm{mmol} / \mathrm{l})$ & No. & $\mathrm{FPG}(\mathrm{mmol} / \mathrm{l})$ & No. & $\mathrm{FPG}(\mathrm{mmol} / 1)$ & No. \\
\hline \multicolumn{9}{|l|}{ Men } \\
\hline $20-39$ & $6.09 \pm 0.08$ & 83 & $5.50 \pm 0.06$ & 118 & $5.65 \pm 0.10$ & 58 & $5.74 \pm 0.08$ & 90 \\
\hline $40-59$ & $6.59 \pm 0.11$ & 135 & $5.97 \pm 0.12$ & 149 & $5.80 \pm 0.12$ & 94 & $5.97 \pm 0.07$ & 164 \\
\hline $60-79$ & $6.36 \pm 0.06$ & 301 & $5.72 \pm 0.05$ & 269 & $5.93 \pm 0.12$ & 169 & $5.97 \pm 0.04$ & 410 \\
\hline \multicolumn{9}{|c|}{ Women not on hormones } \\
\hline $20-39$ & $5.79 \pm 0.11$ & 68 & $5.33 \pm 0.07$ & 110 & $5.30 \pm 0.12$ & 56 & $5.52 \pm 0.07$ & 93 \\
\hline $40-59$ & $6.09 \pm 0.09$ & 100 & $5.40 \pm 0.08$ & 105 & $5.84 \pm 0.21$ & 71 & $5.79 \pm 0.08$ & 115 \\
\hline $60-79$ & $6.07 \pm 0.06$ & 237 & $5.60 \pm 0.05$ & 201 & $5.81 \pm 0.11$ & 141 & $5.80 \pm 0.07$ & 297 \\
\hline \multicolumn{9}{|c|}{ Women on hormones } \\
\hline $20-39$ & $5.66 \pm 0.14$ & 25 & $5.08 \pm 0.14$ & 28 & $5.18 \pm 0.22$ & 26 & $5.27 \pm 0.10$ & 31 \\
\hline $40-59$ & $5.87 \pm 0.10$ & 77 & $5.43 \pm 0.08$ & 86 & $5.43 \pm 0.14$ & 62 & $5.56 \pm 0.06$ & 128 \\
\hline $60-79$ & $6.17 \pm 0.10$ & 101 & $5.45 \pm 0.06$ & 107 & $5.50 \pm 0.13$ & 66 & $5.86 \pm 0.17$ & 170 \\
\hline
\end{tabular}

Results expressed as mean \pm SEM 


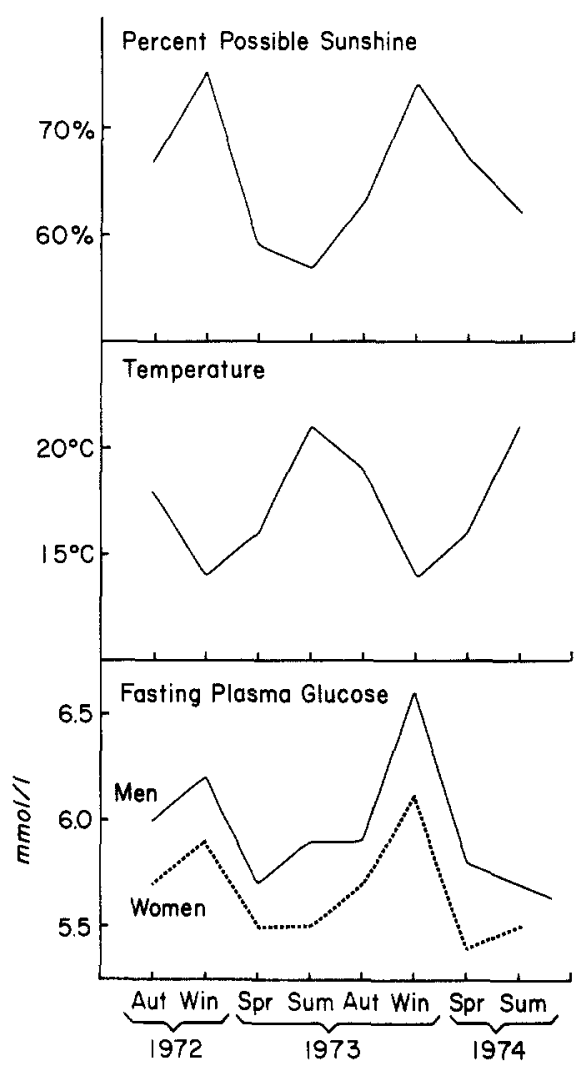

Fig. 2. Seasonal variation in percentage possible sunshine, air temperature and fasting plasma glucose levels occurring over a 2-year period (1972-1974). Aut = autumn; Win = winter; Spr = spring; Sum $=$ summer

Table 3. Seasonal variation in fasting plasma glucose (FPG) levels adjusted for age and obesity index

\begin{tabular}{llllll}
\hline & \multicolumn{2}{l}{ Men } & & \multicolumn{2}{l}{ Women } \\
\cline { 2 - 3 } & FPG $(\mathrm{mmol} / \mathrm{l})$ & No. & & FPG $(\mathrm{mmol} / \mathrm{l})$ & No. \\
\hline December-February & $6.37 \pm 0.05$ & 519 & & $6.01 \pm 0.04$ & 608 \\
March-May & $5.74 \pm 0.04$ & 535 & & $5.46 \pm 0.04$ & 637 \\
June-July & $5.86 \pm 0.06$ & 321 & & $5.62 \pm 0.05$ & 422 \\
August-November & $5.94 \pm 0.04$ & 664 & & $5.71 \pm 0.04$ & 834 \\
& $p<0.0001$ & & & $p<0.0001$ & \\
\hline
\end{tabular}

Results expressed as mean \pm SEM

Table 4. Average weight change by season

\begin{tabular}{|c|c|c|c|c|}
\hline & \multicolumn{2}{|l|}{ Men } & \multicolumn{2}{|l|}{ Women } \\
\hline & $\begin{array}{l}\text { Weight } \\
\text { change (kg) }\end{array}$ & No. & $\begin{array}{l}\text { Weight } \\
\text { change (kg) }\end{array}$ & No. \\
\hline $\begin{array}{l}\text { December- } \\
\text { February }\end{array}$ & $0.045 \pm 0.036$ & 52 & $0.018 \pm 0.073$ & 81 \\
\hline March-May & $-0.150 \pm 0.095$ & 116 & $-0.091 \pm 0.086$ & 124 \\
\hline June-August & $-0.082 \pm 0.132$ & 61 & $-0.068 \pm 0.109$ & 86 \\
\hline $\begin{array}{l}\text { September- } \\
\text { November }\end{array}$ & $-0.159 \pm 0.100$ & 75 & $-0.005 \pm 0.059$ & 91 \\
\hline
\end{tabular}

Results expressed as mean $\pm \mathrm{SEM}$

\section{Discussion}

These data show a significant $0.6 \mathrm{mmol} / 1$ seasonal variation in FPG consistent across a broad age range and for both sexes. The temperate climate of San Diego has the smallest seasonal variation in temperature (range of $13{ }^{\circ} \mathrm{C}$ in winter to $23^{\circ} \mathrm{C}$ in summer for the years of study) of any major city in North America. Nevertheless the amount of seasonal variation in FPG observed in San Diego was similar to that reported from arctic and subarctic climates.

Ecological correlations do not, of course, imply causality. The seasonal variation in FPG could also reflect seasonal patterns in obesity, diet and/or exercise, individual determinants of FPG [10-15]. Others have shown that caloric intake increases with increasing cold [16-18], but no seasonal differences in total calories or specific nutrients were found in this sample, given the recognized limitations of 24 -h diet recall methodology. In this climate where outdoor exercise is feasible throughout the year, there was also no significant seasonal variation in reported exercise.

The obesity index varied by season, with the highest levels in winter corresponding to the highest FPG levels. However, seasonal variation in FPG remained essentially unchanged after adjustment for obesity. Weight reduction has been shown to reduce FPG [11] and to be seasonal; under stable restriction of calories weight reduction is most difficult in winter months and most successful in the spring [19]. Correspondingly, in this population weight gain was reported only for winter months. If a seasonal pattern of weight change rather than current obesity is a determining factor of seasonal FPG variation, the weight change could alter FPG levels via hormonal or receptor mechanisms. The two major hormones known to affect glucose homeostasis, insulin which lowers FPG and glucagon which raises it, have been shown by others to have seasonal variation [20-21].

Seasonal variation in FPG across animal species suggests an evolutionary ecological mechanism. These data also suggest that caution and appropriate controls are necessary whenever drug, diet, or other behavioural changes are implicated in changing FPG levels.

Acknowledgements. Research supported by: National Institutes of Health Contract No. NIH-NHLBI-HV-1-2160-L and by grants from the San Diego Chapter of the American Diabetes Association and Calbiochem-Behring Corporation of San Diego.

\section{References}

1. National Diabetes Data Group (1979) Classification and diagnosis of diabetes mellitus and other categories of glucose intolerance. Diabetes 28: 1039-1057 
2. Culhane K (1928) The use of rabbits in insulin assay. Q J Pharm $1: 515-533$

3. DiMaggio A, Dessauer HC (1963) Seasonal changes in glucose tolerance and glycogen disposition in a lizard. Am J Physiol 204: 677-680

4. Young DAB (1965) Hypothalamic (photoperiodic) control of a seasonal antagonism to insulin in the rat heart. J Physiol 178: 530-543

5. Arvill A, Ahren K (1967) Effects of insulin on the intact levator ani muscle of the rat. Acta Endocrinol 56:279-294

6. Laurila M, Suomalainen P (1974) Studies in the physiology of the hibernating hedgehog. 19. The changes in the insulin level induced by seasons and hibernation cycle. Ann Acad Sci Fenn Ser A 4201: 1-40

7. Castex Ch, Donnio R, Sutter BChJ (1979) Seasonal variations in plasma glucose and insulin concentrations after glucose loading in the edible dormouse (Glis glis L.)T Physiol [Paris] 75: 283-288

8. Fahlén M, Odén A, Bjorntorp P, Tibbin G (1971) Seasonal influence on insulin secretion in man. Clin Sci 41: 453-458

9. Campbell IT, Jarrett RJ, Keen H (1975) Diurnal and seasonal variation in oral glucose tolerance: studies in the Antarctic. Diabetologia 11: 139-145

10. Barrett-Connor E (1980) Factors associated with the distribution of fasting plasma glucose in an adult community. Am J Epidemiol 112:518-523

11. Farinaro E, Stamler J, Upton M, Mojonnier L, Hall Y, Moss D, Berkson DM (1977) Plasma glucose levels: Long-term effect of diet in the Chicago Coronary Prevention Evaluation Program. Ann Intern Med 86: 147-154

12. Himsworth HP (1935) The dietetic factor determining the glucose tolerance and sensitivity to insulin of healthy men. Clin Sci 2: 67-94
13. Grey N, Kipnis DM (1971) Effect of diet composition on the hyper-insulinemia of obesity. N Engl J Med 285: 827-831

14. Munoz JM, Sandstead HH, Jacob RA (1979) Effects of dietary fiber on glucose tolerance in normal men. Diabetes $28: 496-502$

15. Vranic M, Berger M (1979) Exercise and diabetes mellitus. Diabetes 28: 147-163

16. Johnson RE, Kark RM (1947) Environment and food intake in man. Science 105: 378-379

17. den Hartog C, van Schaik TFSM, Dalderup LM, Drion EF, Mulder T (1965) The diet of volunteers participating in a longterm epidemiological field survey on coronary heart disease at Zutphen the Netherlands. Voeding 26: 184-208

18. Marr JW (1967) Seasonal differences in the diets of male bank staff. In: Kühnau J (ed) Seventh International Congress of Nutrition, vol 5. Friedrich Vieweg Verlag, Braunschweig, p 39.

19. Zahorska-Markiewicz B (1980) Weight reduction and seasonal variation. Int J Obes 4: 139-143

20. Kuroshima A, Doi K, Ohno T (1979) Seasonal variation of plasma glucagon concentrations in men. Jpn J Physiol 29: 661-668

21. Campbell IT, Jarrett RJ, Rutland P, Stimmler L (1975) The plasma insulin and growth hormone response to oral glucose: diurnal and seasonal observations in the Antarctica. Diabetologia 11: $147-150$

Received: 15 June 1981

and in revised form: 3 September 1981

Elizabeth Barrett-Connor, M. D.

Department of Community and

Family Medicine M-007

University of California

San Diego, CA 92093, USA 